\title{
Oedematousskin Disease in Buffaloes and Cows
}

\author{
Sahar R. Mohamed* and Lamyaa M. Reda** \\ *Animal Health Research Institute and ${ }^{* *}$ Central laboratory of \\ Veterinary Hospital, Faculty of Veterinary Medicine, Zagazig \\ University, Egypt.
}

\begin{abstract}
RUFFALOES examined during summer 2006, out of 176 buffaloes out of 176 buffaloes examined 46 animals proved to be contract proved to be contract the disease representing a morbidity rate of $26.1 \%$. On the other hand, out of 120 examined cows, 20 proved to be infected with the disease representing a morbidity rate of $16.6 \%$. Concerning the clinical signs that observed in this epidemic, the disease occurred in 4 forms. The first is the edematous form which appeared in buffaloes more than in cattle. The second form was the ulcerative form, and it was more common in cattle than buffaloes. The $3^{\text {td }}$ was the nodular form and the $4^{\ln }$ form was the mixed, the bacteriological examination, showed symptoms of edematous skin disease Corynebacterium pseudotuberculosis was isolated as a single infection. The phospholipase D toxin bands of the isolated pathogens were in a molecular size of 37 and $39 \mathrm{KDa}$. Serological investigation by using agar gel immunodiffusion test was strongly positive in serum samples. On the other hand, the OD reading of ELISA above the cut off point $(0.28)$ was recorded in serum samples.
\end{abstract}

Keywords: Corynebacterium pseudotuberculosis, Cows, Buffaloes, Phospholipase D toxin.

Buffaloes may consider the principle sector of livestock in Egypt. It represents the main source for meat and milk production (Radostits et al., 2007). This sector had been exposed to different infectious diseases with great economic impact. One of the most serious and specific infectious diseases is the so called edematous skin disease(Sood et al., 2012). It was reproduced experimentally in buffalo calves by pure colonies of $C$. pseudotuberculosis (Khater et al., 1984). Therefore, the disease was reported in a cyclic nature at different governorates of Egypt, Sharkia (Mostafa, 1984, Abdel Galil et al., 1986 and Abu Zaid, 2001), Assiut (Khalil et al., 1995) and Gharbia (Al-Gaabary \& Ammar, 1999 and Mahmoud, 2009).

Edematous skin disease is also named ulcerative lymphangitis which often appeared as seasonal outbreaks during late spring .and early summer months where insects may play a role in the dissemination of the disease (Fouad et al., 1974, Barakat, 1980, Addo, 1983 and Braverman et al.,1999). In between the cycles of epidemic it may appeared sporadically (Mostafa, 1984 and Al-Gaabary \& Ammar, 1999). 
The disease was characterized by low mortality and high morbidity (Khalil et al., 1995) and clinically by hot painful inflammatory swelling appeared at different areas of the skin and the lymph vessels draining the inflamed area appeared as cord. The local lymph node was swollen reaching the size of watermelon. Necrosis and ulceration of the skin were also seen (Soliman et al., 1970 and Hamoda, 1996). The condition of diseased animals is fair with little change in appetite, decreased milk yields and slight rise in body temperature. In addition, lameness may be noticed (Al-Gaabary \& Ammar, 1999 and Abu Zaid, 2001).

\section{Material and Methods}

\section{Animals}

Field animals

A total of 176 buffaloes and 120 cattle aged from 6 months up to 7 years at El-Fauom Governorate was investigated in this study. Some of them were suffering from skin lesions in the form of diffuse edematous swelling in different parts of skin, ulceration and/or nodular lesions.

\section{Experimental animals}

Eight male guinea pigs of about 250-350 g body weight were obtained from the serum and Vaccine Research Institute, Abbasia, Cairo. Egyptwere used in isolation $\mathrm{f}$ the Coryne bacterium pseudoiitberculosisas well as determination of its pathogenicity.

\section{Sensitivity discs}

\section{Bacteriological examination}

Double samples were collected from each lesion either by aspiration from closed lesions or via cotton swabs from open lesions. All samples were taken under complete aseptic conditions and used for both direct smear and isolation of the causative agent by culturing onto $10 \%$ sheep blood agar, nutrient agar and MacConkey's agar plates then incubated at $37^{\circ} \mathrm{C}$ for 48 hours aerobically as well as in $\mathrm{CO}_{2}$ incubator for the first isolation according to the method described by Bailey and Scott (1990).

\section{Pathogenicity test in guinea pigs}

Six guinea pigs were inoculated subcutaneously with $0.25 \mathrm{ml}$ of $24 \mathrm{hrs}$ broth culture of the isolated microorganisms. At the same time 2 animals (as controls) were inoculated with sterile broth by using the same dose and route of inoculation according to El-Far (1976).

- Detection of phospholipase D-antigen, which is produced by $C$. pseudotuberculosis cells. The isolates were cultivated in brain heart infusion broth, incubated and agitated at $37^{\circ} \mathrm{C}$ for $36 \mathrm{hrs}$. the bacteria were removed by centrifugation at $5000 \mathrm{rpm}$ for 10 minutes at $4 \mathrm{C}$ in cooled centrifuge and then filtered. Culture supernatant fluids were dialyzed overnight.

Egypt. J. Vet. Sci. Vol. 45-46 (2014 - 2015) 
- Detection of C. pseudotuberculosis antibodies by:

a. Agar gel immunodiffusion test according to Muckle and Menzies (1992). Nobel agar with sodium azide were prepared. The central well of each hexagonal pattern was filled with prepared (PLD) toxins and the peripheral wells were filled with tested serum. After incubation at $37^{\circ} \mathrm{C}$ for $24 \mathrm{hrs}$, the plates were examined for the presence of sharp white precipitation lines.

b. Sodium dodocylesuphate (SDS) - polyacrylamide gel electrophoresis (SDS-PAGE).

c. ELISA according to Menzies et al. (1994). Indirect ELISA performed by coating microtiter plates with phosphorlipase D (PLD).

\section{Results and Discussion}

Edematous skin disease is an endemic infectious disease that appears mainly among buffaloes and occasionally cattle in Egypt. The disease is usually confined to Lower Egypt as a result of the suitable climatic conditions (low temperature and high relative humidity) especially during late spring and early summer months. On the contrary the disease is less frequent in Upper Egypt due to the considerably high temperature and low relative humidity (Selim, 2001).

Out of the examined 176 buffaloes, 46 showed clinical signs of edematous skin disease and 2 of these infected animals were died representing a morbidity rate $26.1 \%$, Similar results were reported by Barakat (1980), Al-Gaabary \& Ammar (1999) and Abu-Zaid (2001). On the other hand out of the. examined 120 cattle, 20 showed clinical signs of the disease representing a morbidity rate $16.6 \%$ whereas no mortalities were recorded (Table 1). Similar results were recorded by Shpigel et al. (1993) and Abu-Zaid \& Hammam (1996). So, it was obvious that the disease was more prevalent in buffaloes than in cattle. These results were in agreement with the results of Soliman et al. (1970), Barakat (1980), Khalil et al. (1995) and Abu Zaid (2001). The variations in the disease frequency between the different studies may be attributed to the endemic nature of the population variable degrees of immunity.

Concerning the age susceptibility, animals from 1-4 years in both buffaloes and cattle reported by Barakat et al. (1984), Al-Gaabary \& Arnrnar (1999) and Shpigel et al. (1999) who described the epidemiological feature of the edematous : skin disease in Egypt. On the other hand, Zaghawa and El-Gharib (1996) found that edematous skin disease was more prevalent in animals lower than 2 years in comparison to those more than 2 years.

The clinical picture associated with the disease appeared in 4 forms (edematous, ulcerative, nodular and mixed forms (Table 2). The described clinical signs and forms of the disease had been previously reported by $\mathrm{Al}$ Gaabary and Ammar (1999).

Egypt. J. Vet. Sci. Vol. 45-46 (2014 - 2015) 
The edematous form was more obvious in buffaloes than in cattle, where it represented 35\% of the cases in buffaloes and 5\% in cattle. On the other hand, the ulcerative form was more prevalent in cattle than that in buffalo where it represents $85 \%$ of the cases in cattle and $6.5 \%$ of the cases in buffaloes (Table 2).

TABLE 1. Morbidity rates in examined animals.

\begin{tabular}{|c|c|c|c|c|}
\hline $\begin{array}{c}\text { Animal } \\
\text { species }\end{array}$ & $\begin{array}{c}\text { Number of } \\
\text { examined } \\
\text { animals }\end{array}$ & $\begin{array}{c}\text { No. of } \\
\text { diseased } \\
\text { animals }\end{array}$ & $\begin{array}{c}\text { No. of dead } \\
\text { animals }\end{array}$ & $\begin{array}{c}\text { Morbidity } \\
\text { rate }\end{array}$ \\
\hline Buffaloes & 176 & 46 & 2 & $26.1 \%$ \\
\hline Cattle & 120 & 20 & - & $16.6 \%$ \\
\hline Total & 296 & 66 & 2 & $22.4 \%$ \\
\hline
\end{tabular}

TABLE 2. Percentage of clinical forms of edematous skin disease.

\begin{tabular}{|l|c|c|c|c|c|c|c|c|c|}
\hline \multirow{2}{*}{ Age } & \multicolumn{2}{|c|}{ Buffaloes } & \multicolumn{2}{c|}{ Cattle } & \multicolumn{3}{c|}{ Total } \\
\cline { 2 - 9 } & $\begin{array}{c}\text { No. of } \\
\text { examined } \\
\text { animals }\end{array}$ & $\begin{array}{c}\text { No. of } \\
\text { diseased } \\
\text { animals }\end{array}$ & $\%$ & $\begin{array}{c}\text { No. of } \\
\text { examined } \\
\text { animals }\end{array}$ & $\begin{array}{c}\text { No. of } \\
\text { diseased } \\
\text { animals }\end{array}$ & $\%$ & $\begin{array}{c}\text { No. of } \\
\text { examined } \\
\text { animals }\end{array}$ & $\begin{array}{c}\text { No. of } \\
\text { diseased } \\
\text { animals }\end{array}$ & $\%$ \\
\hline $\begin{array}{l}\text { Edematous } \\
\text { form }\end{array}$ & 46 & 35 & 76 & 20 & 1 & 5 & 66 & 36 & 54.5 \\
\hline $\begin{array}{l}\text { Ulcerative } \\
\text { form }\end{array}$ & 46 & 3 & 6 & 20 & 17 & 85 & 66 & 20 & 30.3 \\
\hline $\begin{array}{l}\text { Nodular } \\
\text { form }\end{array}$ & 46 & 3 & 6 & 20 & 2 & 10 & 66 & 5 & 7.6 \\
\hline
\end{tabular}

Khater et al. (1983) reported that the skin of cattle especially the epidermis and dermal layers were relatively thinner than that in buffaloes. So, the great thickness of the dermis in buffaloes especially at shoulder region and posterior aspect of thigh with the presence of high vascularity and plenty of macrophage might create a favorable media for Corynebacterium pseudotuberculosis infection in severe form (edematous form).

The edematous swelling observed in I the edematous form might be occurred as a result of inflammatory activity of exotoxin mainly phospholipase D (PLD) produced by the causative organism. This effect is not, only locally but also systemically through the circulation to cause toxemia (Selim, 2001).

The phospholipase $\mathrm{D}$ toxin of the examined isolated strains of $C$. pseudotuberculosis was resolved by SDS-PAGE. The toxin bands were in a molecular size of 37 and $39 \mathrm{KDa}$ as shown in (Fig. 1).

Locally the activity of PLD as its affect on its biological and enzymatic characters. The biological activity is expressed by development of severe inflammation in the surrounding blood vessels and lymphatics. The local edema is increased by the direct enzymatic effect of PLD on the phospholipids in the

Egypt. J. Vet. Sci. Vol. 45-46 (2014 - 2015) 
mast cells resulting in the formation of arachidonic acid which is acted upon by certain enzymes to produce histamine like substances such as leukotrins and prostaglandins (Crinio et al., 1998).

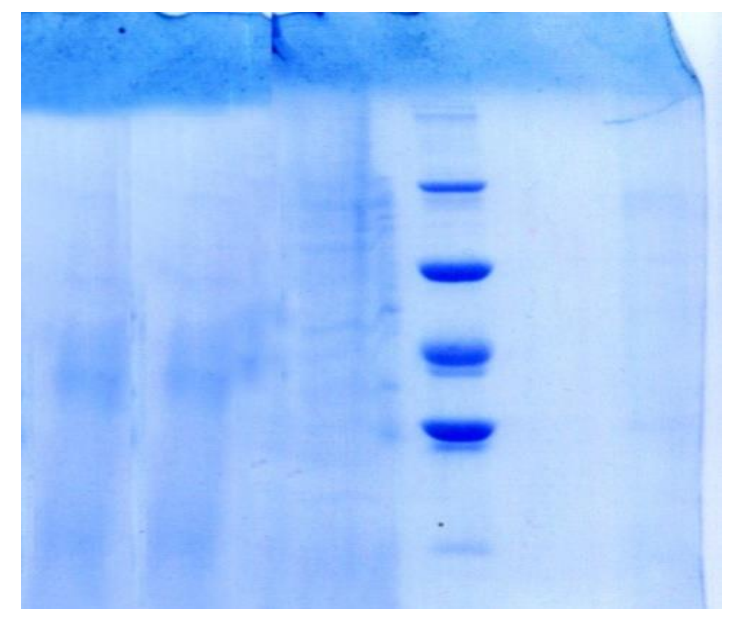

Fig.1. Characterization of phospholipase-D (of C. pseudotuberculosis) of buffalo and cow by SDS (immun blot).

Selim (2001), Aleman \& Spire (2002) and Yeruham et al. (2003) referred the inflammatory process and local edematous swelling around lesions which occurred usually during edematous skin disease to the organism's putative virulencefactors mainly to the direct effect of phospholipase D I exotoxin in the surrounding blood vessels and lymphatics. Also, they reported that the phospholipase Dexotoxin has a general toxemic influence on internal organs in addition the cell wall lipid of Corynebactermm pseiidotuberculosis have a potent necrotic effect on the surrounding tissues (Amir and Mahmoud, 2012).

Brown \& Olander (1987) and Lioyd (1994) showed that the protective nature of the cell capsule enables the bacterium to persist in the environment for extended periods under favorable conditions: damp, shady areas and low temperatures (Amagai et al.,2006).

The microbiological examination, Corynebacterium pseudotuberculosis was isolated as a single infection from 53 cases in both buffaloes and cattle samples (80.3\%), These results were coincided with the results of Soliman et al. (1970), Abu-Zaid (2001) and El-Sawah (2002).

Concerning the biochemical characters of the isolated Corynebacterium pseudoluberculosis, all the isolated strains from buffaloes and cattle were nitrate positive. This comes in agreement with Biberstein et al. (1971), Hassan (1988),

Egypt. J. Vet. Sci. Vol. 45-46 (2014 - 2015) 
Galila (1998), Zaki (1999) and Selim (2001). While, other authors have reported that both types (nitrate positive and nitrate negative) might be isolated from cattle (Yeruham et al., 1997 and Steinman et al., 1999).

Concerning guinea pigs inoculation for studying both pathogenesis and reisolation, all the inoculated isolates of Corynebacterium pseudotuberculosis killed guinea pigs within 2-4 days post injection where the dead guinea pigs showed congestion and maceration of muscles at site of injection in addition to congestion of the internal organs. This comes in agreement with the findings of Barakat (1984), Khater et al. (1984), Tawfik (1990), Galila (1998) and El-Sawah (2002).

Serological examination, using agar gel immune diffusion test (Table 3), gave strong positive results. ELISA of examined serum samples (Table 4) revealed (OD) reading above the cut off point (0.28). These results suggest that the ELISA is more sensitive for detecting antibodies against $C$. pseudotuberculosis (Abramovits, 2005).

Soliman et al. (1970), Mostafa (1984) and Spiegel (1993) found that the isolated strains of Corynebacterium pseudotuberculosis were highly sensitive to penicillin in vitro. While Abd El-Galil et al. (1986), Khalil et al. (1995) and AlGaabary \& Ammar (1999) found the isolated strains was highly sensitive in vivo and in vitro to gentamycin. Whereas Zaki (1999) found that the isolated strains was highly sensitive to enrofloxacin. Sehra et al. (2008).

These variations in the results of sensitivity tests and also in .recovery rates might be due to the development of some resistance against certain antimicrobial drugs which used in previous outbreaks.

TABLE 3. Agar gel immunodiffusion of buffalo and cow sera using (PLD).

\begin{tabular}{|l|c|c|c|c|}
\hline \multirow{2}{*}{$\begin{array}{c}\text { Serum samples } \\
\text { examined }\end{array}$} & \multicolumn{2}{|c|}{ Positive } & \multicolumn{2}{c|}{ Negative } \\
\cline { 2 - 5 } & No. & $\%$ & No. & $\%$ \\
\hline Buffalo (46) & 31 & 67.4 & 15 & 32.6 \\
\hline Caws (20) & 11 & 55 & 9 & 45 \\
\hline
\end{tabular}

TABLE 4. Optical density (OD) values of buffalo and cow sera using (PLD) as coating antigen.

\begin{tabular}{|l|c|c|c|c|}
\hline $\begin{array}{c}\text { Antigen } \\
\text { PLD }\end{array}$ & Max. & Min. & Mean & Cut point \\
\hline Buffalo & 0.843 & 0.345 & 0.751663 & 0.28 \\
\hline Cow & 0.653 & 0.382 & 0.643551 & 0.28 \\
\hline
\end{tabular}

Egypt. J. Vet. Sci. Vol. 45-46 (2014 - 2015) 


\section{References}

Abd El-Galil, Y., Ammar, M.I., Yousef, F.H. and Kenavvy, A. (1986) Clinical and bacteriological studies of OSD in buffaloes and camels in Sharkia Governorate. Zag. Vet. J., 8 (1), 268-277.

Abramovits, W. (2005) Atopic dermatitis. J Am Acad Dermatol, 53, S86-93.

Abu-Zaid, A.A. (2001) Corynebacteriumpseudoliiberculosisin buffaloes, ass and sheep. Vet. Med. J. Giza, 49 (3), 435-450.

Abu-Zaid, A.A. and Hammam, H.M. (1994) Studies on some skin affection in cattle 2ulcerative lymphangitis $6^{\text {th }}$ Sci. Cong. 22-20 Nov. pp. 523-531, Fac. Vet. Med., Assiut, Egypt.

Addo, P.B. (1983) Role of the common house fly (Muscadomestica) in the spread of ulcerative lymphangitis. I. Vet. Record, 113, 496-497.

Aleman, M.R. and Spier, S.J. (2002) Corynebacteriwnpseudotuberculosis infection in "Large Animal Internal Medicine" $3^{\mathrm{d}}$ ed. Smith P.R. (Ed.) St. Louis, Mosby Company, pp. 1076-1084.

Al-Gaabary, M.H. and Ammar, K. (1999) Clinical and epidemiological studies on buffaloes lymphangitis in Gharbia Governorate. $5^{\text {th }}$ Sci. Conf. Egyptian Society for Cattle Disease, pp. 89-97.

Amagai M., Matsuyoshi N., Wang Z., Andl, C. and Stanley J. (2006) Toxin in bullous impetigo and staphylococcal scalded-skin syndrome targets desmoglein 1. Nat Med., $1275-1277$.

Amir, H.A. and Mahmoud, T. (2012) The role of chorioptic manage infestation in aggravating the infection rates of staphylococcal dermatitis and edematous skin disease in Egyptian buffaloes. Life science Journal, 9 (1), 131-141

Bailey, A. and Scott S. (1990) Diagnostic microbiology $8^{\text {th }}$ edition the C.V. Mosby Company. St. Louis.

Barakat, A.A. (1979) Edematous skin disease project $1^{\text {st }}$ Ann. Report. Gront No. FG.EG 189. Project No. EG.ASR 86. Animal Health, Research Institute, Dokki, Cairo, Egypt.

Barakat, A.A. (1980) "Cotynebactenumovisin Cattle Skin Edematous Disease", $2^{\text {nd }}$ Ann. Report. April U.S. Agriculture Res. Program. Public. Law. 480 p.

Barakat, A.A. and Eid, F.I.A. (1971) Bovine Lymphangitis monthly report, Vet. Dep. Animal Health Research Institute, Dokki, Cairo. Egypt, pp. I-10.

Barakat, A.A., Selim, S.A., Atef, M.S., Nafie, E.K. and El-Ebeedy, A.A. (1984) 2 serotype of Corynebacterium pseudostiiberculosis isolated from different animal species. Rev. Sci. Techn., Int. Epiz., 3 (1), 151-163.

Egypt. J. Vet. Sci. Vol. 45-46 (2014 - 2015) 
Biberstein, L., Knight, D. arid Spenger, F. (1971) Two biotype of Corynebacterium pseudotuberclosis. Vet. Record, 12, 691-692.

Braverman, Y., Chizov-Ginzburg, A., Saran, A. and Winkler, M. (1999) The role of house flies (Muscadometica) in harbouring Corynebacterium pseudotuberculosis in dairy herds in Israel. Res. Sci. Tec., 18 (13), 681-690.

Brown, C.C. and Olander, H.J. (1987) Caseous lymphadenitis of goats \& sheep: a review. Vet. Bull., 57 (1), 1-18.

Crinio, G., Antunes, E. and Nucci, G. (1998) Mast cell degeneration induced by two phospholipase $\mathrm{A}_{2}$ homologues, dissociation between enzymatic and biological active. Eur. J. Pharmacol., 343 (2-3), 257-263.

El-Far, F.A. (1976) Comparative bacteriological studies on C. ovis strains isolated from sheep, goats and bovine sources in Egypt. M.V.Sc. Thesis, (Bacteriology) Cairo, University.

El-Sawah, A. (2002) Studies on Corynebacterium pseudotuberculosis infection in buffaloes. Ph.D. Thesis, (Infectious Diseases) Cairo University.

Fouad, K., Saleh, M., Khamis, Y., Shouman, F. and Fahmy, L.S. (1974) Further investigation on the so called edematous skin disease: of buffaloes and cattle. Proc. $10^{\text {th }}$ Arab Ann. Vet. Cong. Cairo, 154-171.

Galila, M.I. (1998) Some studies on edematous skin disease. M.V.Sc. Thesis, (Infectious Diseases) Zagzig University.

Harnoda, F.K. (1996) Some studies on edematous skin disease. J. Egypt. V. Vet. Med. Assoc., 56 (2), 213-221.

Hassan, M.K. (1988) Studies on some infectious diseases causing edema in buffaloes. M.V.Sc. Thesis, (Infectious disease) Cairo University.

Khalil N.G., Seddek, S.R. and Nashed, S.M. (1995) Studies on ulcerative lymphangitis in buffaloes in Assiut. Assiut Vet. Med. J., 33 (65), 93-99.

Khater, A.R., Bayoumi, A.N., El-Deeb, S. and Salem, H. (1984) Studies on experimental infection of C. ovls.II. Comparative studies on the effect of 2 strains in sheep. Assiut Vet. Med. J., 11(21), 95-99.

Khater, A.R., Sherry, M.I. and Barakat, A.A. (1977) The pathogenesis of C. ovis in guinea pigs. Assiut. Vet. Med. J., 4 (8), 89-101.

Lioyd, S. (1994) Caseous lymphadenitis in sheep and goats. In Practice, 16, 24-29.

Mahmoud, A.A. (2009) "Animal infectious diseases" $7^{\text {th }}$ ed. pp. 130-133. Faculty of Veterinary Medicine, Alexandria University, Egypt.

Menzies, P.I., Muckle, C.A., Hwang, Y.T. and Songer, J.G. (1994) Evaluation of an enzyme linked immunosorbent assay for the diagnosis of Corynebacterium pseudotuberculosis infection. Small Ruminant Res., 13 (2), 193-198.

Egypt. J. Vet. Sci. Vol. 45-46 (2014 - 2015) 
Mostafa, E. (1984) Studies on the so called edematous skin disease. M.V.Sc. Thesis, Zagazig University.

Radostits, O.M., Gay, C.C., Hinchcliff, K.W. and Constable, P.D. (2007) "Veterinary Medicine", $10^{\text {th }}$ ed. pp. 798-799. Saunders, Philadelphia.

Selim, S.A. (2001) Review: Edematous: skin disease of buffaloes in Egypt. Vet. Med. J. B., 48, 241-258.

Shpigel, N.Y., Elad, D., Yeruham, I., Minklor and Saran, A. (1993) An outbreak of Corynebacterium pseudotuberculosis infection in an Israeli Dairy herd. Vet. Record, 133, 89-94.

Soliman, K.N., Zaki, M.M., Sayour, E.M. and El-Hinaidy, H.K. (1970) The role of genus Corynebacteriumin 'animal ' disease with special reference to species of significance Proc., $7^{\text {th }}$ Orali Ann. Vet. Long. Cairo, Egypt, 272-299.

Steinman, A., Elad, D. and Shpigel, N.Y. (1999) Ulcerative lymphangitis and coronet lesions in Israeli dairy herd infected with Corynebacterium pseiidotiibercidosis. Vet. Record, 145 (21), 604-606.

Tawfik, A.M. (1990) Pathological studies of edematous skin disease. Egypt. J. Comp. Path., 3 (1), 1-15.

Tizard, I.R. (1996) "An introduction to Veterinary Immunology" $5^{\text {th }}$ ed., W.R. Saunders. Company, Toronto.

Yeruham, L. Elad, D., Fridmans, A. and Repi, S. (2003) Corynebactemm pseudotuberculosis infection in Israeli dairy cattle. Epidemiology. Infect., 131, 947-955.

Yeruham, I., Elad, D., Van Ham, M. Shpigel, M. and Skcrri, N.Y. (1997) Corynebacterium Pseudotuberculosis infection in Israel Cattle: Clinical and \& $r$ Epidemiological Studies. Vet. Record, 140, 423-427.

Zaghawa, A.A. and El-Gharib, S.A. (1996) An outbreak of edematous! skin disease in Alexandriadurina 1994. Clinical investigation and assessment of epidemiologies parameters. Sci. Cong. 17-19 Nov. 1996, Fac. Vet. Med., Assiut, Egypt, 617-636.

Zaki, E.R. (1999) Bacteriological studies on edematous skin disease in buffaloes at ElMinia. $5^{\text {th }}$ Sci. Conference Egypt. Soc. for Cattle disease, Assiut, pp. 201-204.

Sehra, S., BarbéTuana, F.M., Holbreich, M., Mousdicas, N., Chang, C.H., Travers, J.B. and Kaplan, M.H. (2008) Scratching the surface: Towards understanding the pathogenesis of atopic dermatitis. Crit. Rev. Immunol., 28 (1), 15-43.

Sood, N.K. Sandhu, B.S. Gupta, K., Narang, D. Vasudeva, K. Singh, N.D. (2012) Mesenteric caseous lymphadenitis in a cow calf caused by Corynebacterieum pseudotuberculosis :a case report. Veterinarni Medicina, 57 (7), 371-375.

(Received 14/7/2014; accepted 24/9/2015)

Egypt. J. Vet. Sci. Vol. 45-46 (2014 - 2015) 


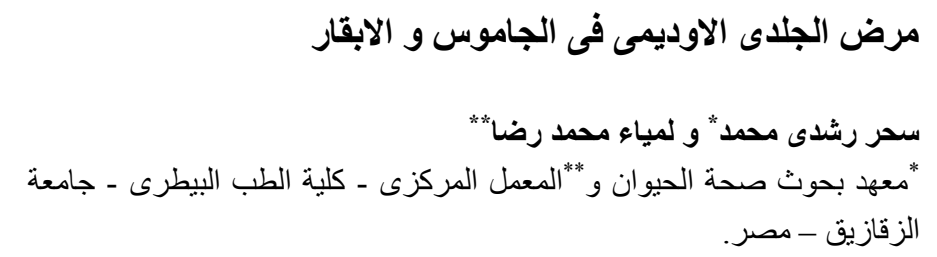

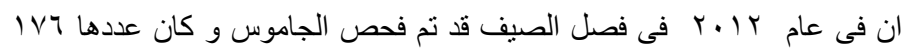

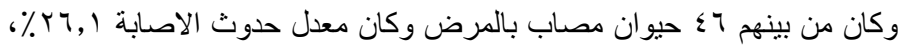

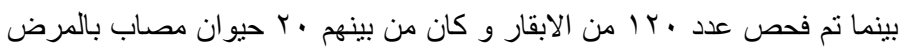

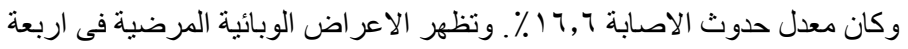

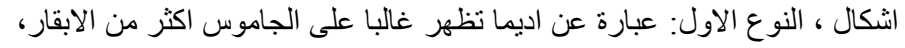

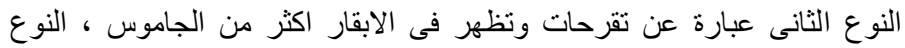

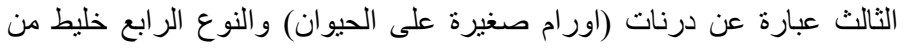

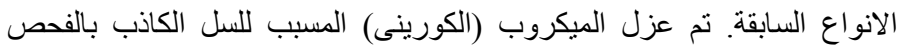

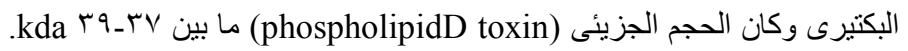

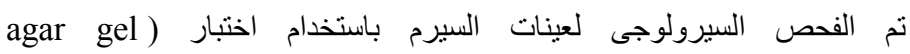
الاليزان وكانت النتائج ايجابية للفحص وتم استخدام اختبار (immunodiffusion test

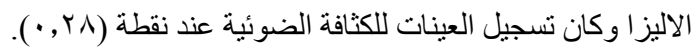

